\title{
ANALISIS PENURUNAN VERTIKAL BANGUNAN BERTINGKAT DI KAMPUS ITS SUKOLILO MENGGUNAKAN METODE TERESTRIAL
}

\author{
Risma Indriya Ludfi ${ }^{1}$, Muhammad Taufik ${ }^{2}$ \\ Departemen Teknik Geomatika, FTSLK-ITS, Kampus ITS Sukolilo, Surabaya, 60111, Indonesia \\ e-mail: ${ }^{1}$ rismaindriyaa@gmail.com, ${ }^{2}$ taufik_m@geodesy.its.ac.id
}

\begin{abstract}
Abstrak
Pembangunan dapat mengakibatkan perubahan kedudukan lahan satu terhadap yang lain sehingga dapat menyebabkan terjadinya pemampatan tanah akibat adanya beban tetap dalam jangka waktu tertentu. Dalam suatu pembangunan gedung, perlu diperhatikan hal-hal yang berkaitan permasalahan kontruksi salah satunya adalah settlement. Settlement adalah penurunan elevasi tanah dasar yang disebabkan oleh lapisan tanah yang mengalami pembebanan di atasnya. Settlement terjadi secara perlahan dan tidak dirasakan secara langsung, sehingga analisisnya perlu dilakukan secara berkala. Tujuan dari penelitian ini adalah untuk menganalisa settlement bangunan di Kampus ITS Sukolilo karena banyaknya bangunan di lokasi yang dapat memberikan dampak pada lapisan tanah dibawahnya seiring dengan waktu. Nilai settlement pada bangunan dapat diketahui dengan melakukan pengukuran beda tinggi terhadap posisi bangunan yang satu terhadap yang lain. Penelitian ini dilakukan dengan melakukan pengukuran deformasi vertikal bangunan atau settlement dengan menganalisa elevasi awal bangunan pada 3 (tiga) bulan terakhir. Dari hasil penelitian, menunjukan bahwa bangunan bertingkat di Kampus ITS Sukolilo mayoritas mengalami penurunan elevasi terhadap Titik Referensi lokal ITS (BM Candi) yang dimiliki oleh Direktorat Sarana dan Prasarana ITS. Bangunan yang mengalami penurunan elevasi setiap bulan adalah Perpustakaan, Gedung Rektorat, Teknik Fisika, Biologi, dan Teknik Elektro. Sedangkan Teknik Geomatika, Teknik Lingkungan, Teknik Sipil, dan Kimia mengalami penurunan dan mengalami kenaikan pada bulan selanjutnya. Bangunan yang mengalami deformasi vertikal berupa penurunan terbesar adalah Teknik Fisika sebesar -0,045 m, dan deformasi berupa kenaikan terbesar adalah Teknik Sipil sebesar +0,035 m.

Kata kunci : Jalur Pengukuran, Elevasi, Bangunan, BM Candi, Settlement
\end{abstract}

\section{PENDAHULUAN}

Pemanfaatan lahan untuk pembangunan akan mengakibatkan terjadinya perubahan kedudukan lahan satu terhadap yang lain. Perubahan ini dapat menyebabkan terjadinya pemampatan tanah akibat adanya beban tetap dalam jangka waktu tertentu. Dalam suatu pembangunan gedung, perlu diperhatikan hal-hal yang berkaitan dengan kontruksi tersebut, salah satunya adalah settlement. Settlement adalah penurunan elevasi tanah dasar yang disebabkan oleh lapisan tanah yang mengalami pembebanan di atasnya, sehingga menyebabkan tanah dibagian bawahnya mengalami kenaikan tegangan (Das 2002). Settlement umumnya terjadi secara perlahan dan tidak dirasakan secara langsung, sehingga analisisnya perlu dilakukan secara berkala.

Institut Teknologi Sepuluh Nopember (ITS) merupakan salah satu perguruan tinggi negeri di Surabaya dan memiliki kampus utama di Sukolilo yang memiliki luas sekitar 188 hektar.
Dengan luas tanah tersebut, kampus ITS menampung puluhan bangunan untuk Program Studi, fasilitas umum, fasilitas olah raga, dan perumahan dosen serta karyawan (Supriyani 2018). Banyaknya pembangunan di lahan Kampus ITS Sukolilo dapat memberikan dampak pada lapisan tanah dibawahnya seiring dengan waktu, salah satu dampak pembangunan tersebut adalah settlement atau penurunan elevasi tanah. Penurunan elevasi tersebut dapat diketahui dengan melakukan pengukuran terhadap posisi bangunan yang satu terhadap yang lain. Oleh karena itu diperlukan penelitian untuk mengamati besar nilai penurunan tanah akibat beban bangunan diatasnya. Penelitian tersebut dilakukan dengan melakukan pengukuran penurunan tanah atau settlement dengan menganalisa elevasi awal bangunan saat pertama kali dibangun dan dibandingkan dengan elevasi hasil pengukuran.

Hasil yang didapatkan dari penelitian ini akan dilakukan evaluasi nilai settlement yang terjadi pada beberapa bangunan bertingkat di Kampus ITS 
Sukolilo dengan membandingkan elevasi bangunan saat awal dibangun dengan elevasi bangunan hasil pengukuran. Diharapkan penelitian ini dapat digunakan sebagai referensi awal dalam mengamati settlement pada bangunan dan dapat dijadikan referensi dalam kebijakan pembangunan bangunan bertingkat selanjutnya di Kampus ITS Sukolilo.

\section{METODOLOGI PENELITIAN}

Lokasi penelitian dilakukan di beberapa bangunan bertingkat yang terletak di Kampus Institut Teknologi Sepuluh Nopember (ITS) Sukolilo Surabaya yang terletak pada koordinat $7^{\circ} 16^{\prime} 54^{\prime \prime}$ LS dan $112^{\circ} 47^{\prime} 41^{\prime \prime}$ BT. Terdapat 9 bangunan bertingkat yang dijadikan bahan penelitian, yaitu:

1. Departemen Biologi ITS

2. Departemen Kimia ITS Gedung J

3. Departemen Teknik Elektro ITS Gedung C

4. Departemen Teknik Fisika Gedung E

5. Departemen Teknik Geomatika ITS Gedung Lama

6. Departemen Teknik Lingkungan ITS Gedung Laboratorium

7. Departemen Teknik Sipil ITS Gedung J

8. Gedung Rektorat ITS

9. Perpustakaan ITS

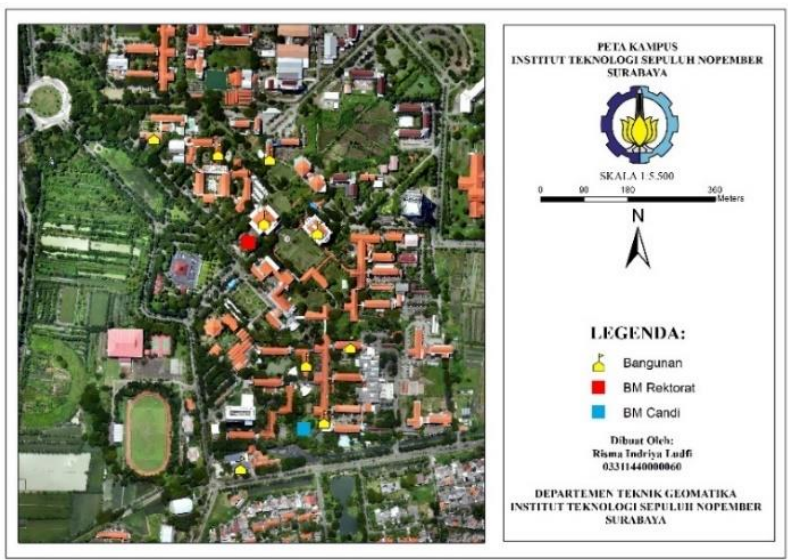

Gambar 1. Lokasi Gedung Penelitian di Kampus ITS

Data yang digunakan dalam penelitian ini yaitu meliputi berikut:

1. Elevasi bangunan bertingkat Kampus ITS Sukolilo pertama kali dibangun.

2. Hasil pengukuran elevasi bangunan bertingkat Kampus ITS Sukolilo tahun 2018.

\section{Peta Kampus ITS Sukolilo.}

Peralatan yang digunakan dalam penelitian ini yaitu alat Sipat datar dengan spesifikasi seperti pada table 1.

Tabel 1. Spesifikasi Sipat datar

\begin{tabular}{ll}
\hline \hline \multicolumn{1}{c}{ Spesifikasi } & \multicolumn{1}{c}{ Keterangan } \\
\hline Field of View & $1^{\circ} 30^{\prime}$ \\
Perbesaran & $30 \mathrm{x}$ \\
Gambar & Tegak \\
Jarak Fokus Minimum & $0,3 \mathrm{~m}$ \\
Range & $\pm 16^{\prime}$ \\
Standar deviasi & $\pm 0,45 \mathrm{~mm}$ \\
\hline \hline
\end{tabular}

Pengukuran beda tinggi menggunakan alat sipat datar terhadap lantai dasar sebagai elevasi 0 bangunan bertingkat. Pengukuran beda tinggi dilakukan secara periodik pada bulan Maret, April, dan Mei 2018. Pengukuran beda tinggi ini dilakukan dengan melakukan pengukuran rangkaian titik setelah itu melakukan pengukuran bangunan.

Pengukuran rangkaian titik dilakukan mulai dari BM Candi sebagai Titik Referensi lokal ITS yang dimiliki oleh Direktorat Sarana dan Prasarana ITS sampai titik paling akhir di gedung Laboratorium Teknik Lingkungan, setelah itu kembali lagi ke BM Candi untuk rangkaian titik pertama. Sedangkan untuk rangkaian titik kedua dilakukan pengukuran mulai dari BM Candi sampai titik akhir di gedung J Departemen Kimia, lalu kembali lagi ke BM Candi. Koreksi yang digunakan pada pengukuran rangkaian titik ini adalah koreksi perataan kuadrat terkecil metode parameter.

Pengukuran beda tinggi menghasilkan elevasi pada titik 0 bangunan. Hasil elevasi pengukuran bulan Maret, April, dan Mei dibandingkan setiap bulannya. Dari perbandingan ini didapatkan evaluasi dinamika pergerakan sebagaian bangunan bertingkat di Kampus ITS selama tiga bulan terakhir.

\section{HASIL DAN PEMBAHASAN}

Berdasarkan data yang diberikan oleh Direktorat Sarana dan Prasarana ITS, pembangunan seluruh bangunan di ITS mengacu pada satu titik yaitu BM Candi yang terletak di lingkungan Departemen Teknik Elektro. BM Candi yang dianggap memiliki elevasi $0,000 \mathrm{~m}$. 


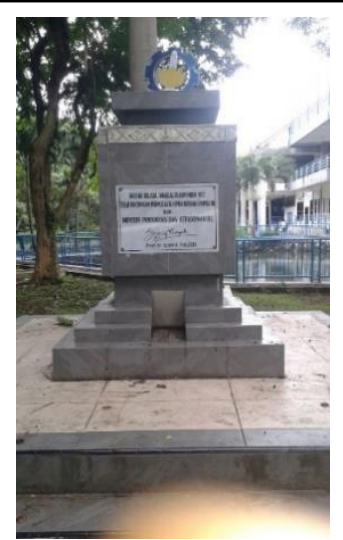

Gambar 2. BM Candi

Hal yang sama dari seluruh bangunan Gedung ITS Titik 0 (nol) bangunan ITS adalah lantai dasar bangunan, sehingga seluruh lantai bangunan dianggap memiliki elevasi $0,000 \mathrm{~m}$. Setiap bangunan di ITS memiliki titik acuan yang dianggap 0 dan mengacu terhadap BM Candi namun tidak ada nilai kuantitatifnya.

Jalur Pengukuran adalah rangkaian titik yang digunakan sebagai acuan dalam melakukan pengukuran deformasi bangunan. Jalur Pengukuran mengacu pada BM Candi. BM Candi digunakan sebagai acuan pada pembangunan seluruh bangunan di ITS dan dianggap memiliki elevasi 0,000 m. Gambar 4 menunjukan rangkaian titik pengukuran yang melewati bangunan-bangunan yang digunakan sebagai objek penelitian tugas akhir ini.

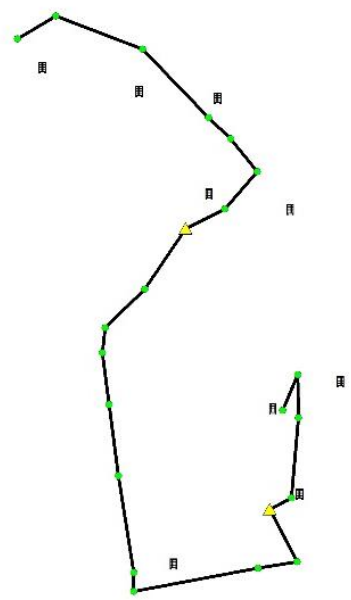

Gambar 3. Jalur Pengukuran untuk penentuan Elevasi

Jalur Pengukuran digunakan sebagai acuan dalam menentukan nilai elevasi bangunan. Oleh karena itu terdapat dua rangkaian titik pada pengukuran ini. Jalur Pengukuran pertama adalah rangkaian titik yang mulai dari BM Candi, melalui bangunan Gedung Rektorat, sedangkan Jalur Pengukuran kedua rangkaian titik melewati bangunan di sekitar Departemen Teknik Elektro. Pengamatan terhadap elevasi Titik 0 (nol) tiap Gedung, dilakukan pengukuran sebanyak 3(tiga) kali, yaitu pada Bulan Maret, April, dan Mei 2018. Pengukuran ini dilakukan berkala setiap bulannya, agar nilai elevasinya dapat dibandingkan setiap kala pengukuran.

Rangkaian titik pengukuran yang tersebar di wilayah kampus ITS Sukolilo Surabaya memiliki jumlah total titik yaitu 21 titik, dimana 1 titik Referensi adalah Benchmark (BM) Candi milik kampus ITS dan 20 lainnya merupakan patok paku. Titik acuan yang digunakan adalah BM Candi yang terletak di depan Departemen Teknik Elektro ITS dengan elevasi dianggap 0,000 m. Dari hasil pengukuran rangkaian titik didapatkan nilai kesalahan penutup seperti berikut:

a. Kesalahan penutup pengukuran bulan Maret 2018 sebesar 5,5 mm untuk Jalur Pengukuran satu, dan $1 \mathrm{~mm}$ untuk Jalur Pengukuran dua.

b. Kesalahan penutup pengukuran bulan April 2018 sebesar $2 \mathrm{~mm}$ untuk rangkaian satu dan $2 \mathrm{~mm}$ untuk rangkaian dua.

c. Kesalahan penutup pengukuranbulan Mei 2018 sebesar $2 \mathrm{~mm}$ untuk rangkaian satu dan $3 \mathrm{~mm}$ untuk rangkaian dua.

Jarak total pengukuran rangkaian satu sepanjang 2,6 km dan rangkaian dua sepanjang $0,5 \mathrm{~km}$, dengan toleransi pengukuran $8 \sqrt{\mathrm{DKm}}$, dengan nilai tersebut maka nilai toleransi kesalahan penutup untuk Jalur Pengukuran satu sebesar $12 \mathrm{~mm}$ dan $6 \mathrm{~mm}$ untuk Jalur Pengukuran dua. Berdasarkan hasil pengukuran, data yang didapatkan pada pengukuran tiga bulan tersebut masuk dalam toleransi.

Tabel 2. Elevasi Rangkaian Titik Pengukuran

\begin{tabular}{cccc}
\hline \hline Titik & Maret $(\mathbf{m})$ & April $(\mathbf{m})$ & Mei $(\mathbf{m})$ \\
\hline 9 & $-0,226$ & $-0,307$ & $-0,393$ \\
8 & $-0,409$ & $-0,409$ & $-0,423$ \\
7 & $-0,181$ & $-0,182$ & $-0,195$ \\
6 & $-0,430$ & $-0,403$ & $-0,385$ \\
5 & $-0,397$ & $-0,400$ & $-0,415$ \\
4 & $-0,406$ & $-0,412$ & $-0,428$ \\
3 & $-0,349$ & $-0,377$ & $-0,423$ \\
2 & $-0,547$ & $-0,555$ & $-0,569$ \\
\hline \hline
\end{tabular}




\begin{tabular}{cccc}
\hline \hline Titik & Maret $(\mathbf{m})$ & April $(\mathbf{m})$ & Mei $(\mathbf{m})$ \\
\hline 1 & $-0,649$ & $-0,656$ & $-0,667$ \\
A & $+0,245$ & $+0,233$ & $+0,223$ \\
B & $-0,464$ & $-0,471$ & $-0,474$ \\
C & $-0,458$ & $-0,468$ & $-0,481$ \\
D & $-0,295$ & $-0,310$ & $-0,328$ \\
E & $-0,308$ & $-0,325$ & $-0,332$ \\
F & $-0,279$ & $-0,294$ & $-0,297$ \\
G & $-0,294$ & $-0,314$ & $-0,317$ \\
BM6 & $-0,615$ & $-0,626$ & $-0,627$ \\
BM7 & $-0,590$ & $-0,628$ & $-0,655$ \\
BM9 & $-0,621$ & $-0,660$ & $-0,688$ \\
BM10 & $-0,616$ & $-0,653$ & $-0,677$ \\
\hline \hline
\end{tabular}

Tabel 2 menampilkan hasil elevasi rangkaian titik pengukuran pada bulan Maret, April, dan Mei 2018 secara berturut-turut setelah dilakukan koreksi menggunakan perataan parameter.

Pengukuran elevasi bangunan dilakukan dengan acuan rangkaian titik seperti yang sudah dibahas pada sub-bab sebelumnya. Pengukuran ini dilakukan dengan meletakkan rambu ukur pada lantai bangunan karena lantai bangunan dianggap memiliki elevasi $0,000 \mathrm{~m}$ terhadap BM Candi. Tabel 2 akan menunjukan nilai elevasi bangunan pada tiga bulan pengukuran.

Tabel 3. Elevasi Bangunan Setiap Bulan

\begin{tabular}{lccc}
\hline \multicolumn{1}{c}{ Bangunan } & Maret $(\mathbf{m})$ & April $(\mathbf{m})$ & Mei $(\mathbf{m})$ \\
\hline Perpustakaan & $-0,555$ & $-0,565$ & $-0,578$ \\
Gedung Rektorat & $-0,664$ & $-0,676$ & $-0,692$ \\
Teknik Geomatika & $-0,406$ & $-0,421$ & $-0,415$ \\
Teknik Fisika & $-0,614$ & $-0,653$ & $-0,698$ \\
Biologi & $-0,308$ & $-0,309$ & $-0,322$ \\
Teknik Lingkungan & 0,030 & 0,010 & 0,028 \\
Teknik Elektro & $-0,552$ & $-0,563$ & $-0,565$ \\
Teknik Sipil & $-0,230$ & $-0,245$ & $-0,210$ \\
Kimia & $-0,351$ & $-0,388$ & $-0,385$ \\
\hline \hline
\end{tabular}

Pada Tabel 3 dapat dilihat perbandingan penurunan elevasi bangunan setiap bulannya. Apabila diamati, mayoritas bangunan di Kampus ITS Sukolilo mengalami penurunan setiap bulan.
Tabel 4. Besar Penurunan Setiap Bulan

\begin{tabular}{lcc}
\hline \multicolumn{1}{c}{ Bangunan } & $\boldsymbol{\Delta h}_{\mathbf{1}}(\mathbf{m})$ & $\boldsymbol{\Delta h}_{\mathbf{2}}(\mathbf{m})$ \\
\hline Perpustakaan & $-0,010$ & $-0,013$ \\
Gedung Rektorat & $-0,012$ & $-0,016$ \\
Teknik Geomatika & $-0,015$ & $+0,007$ \\
Teknik Fisika & $-0,039$ & $-0,045$ \\
Biologi & $-0,001$ & $-0,013$ \\
Teknik Lingkungan & $-0,020$ & $+0,018$ \\
Teknik Elektro & $-0,011$ & $-0,002$ \\
Teknik Sipil & $-0,015$ & $+0,035$ \\
Kimia & $-0,037$ & $+0,003$ \\
\hline \hline
\end{tabular}

Tabel 4 menampilkan besar penurunan bangunan setiap bulan. $\Delta \mathrm{h} 1$ adalah selisih elevasi pada bulan Maret dengan bulan April 2018, dan $\Delta$ h2 adalah selisih elevasi pada bulan April dengan bulan Mei 2018. Berdasarkan Tabel 4 dapat dilihat bangunan yang mengalami penurunan terbesar adalah Teknik Fisika dengan besar nilai $-0,045 \mathrm{~m}$, sedangkan bangunan yang mengalami nilai penurunan terkecil adalah Teknik Elektro dengan nilai -0,002 m. Selain itu, terdapat beberapa bangunan yang juga mengalami kenaikan seperti Teknik Geomatika, Teknik Lingkungan, Teknik Sipil, dan Kimia.

Pengukuran deformasi vertikal bangunan dilakukan dengan mengamati besar nilai penurunan dari empat sisi bangunan setiap bulannya. Pengukuran dari empat sisi bangunan ditujukan agar peneliti dapat mengamati besar penurunan yang terjadi pada bangunan di setiap sisinya, untuk mencegah terjadinya patah pada bangunan. Dibawah ini adalah hasil evaluasi penurunan bangunan dilihat dari empat sisi bangunan.

Gedung Perpustakaan Pusat ITS

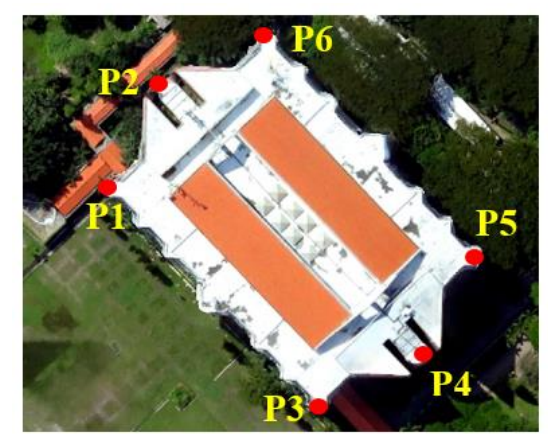

Gambar 4. Posisi Titik Pengamatan di Gedung Perpustakaan Pusat ITS 
Tabel 5. Besar Penurunan Gedung Perpustakaan Pusat ITS

\begin{tabular}{cccccc}
\hline \hline Titik & $\begin{array}{c}\text { Maret } \\
(\mathbf{m})\end{array}$ & $\begin{array}{c}\text { April } \\
(\mathbf{m})\end{array}$ & $\begin{array}{c}\text { Mei } \\
(\mathbf{m})\end{array}$ & $\begin{array}{c}\mathbf{\Delta h}_{\mathbf{1}} \\
(\mathbf{m})\end{array}$ & $\begin{array}{c}\mathbf{\Delta h}_{\mathbf{2}} \\
(\mathbf{m})\end{array}$ \\
\hline P1 & $-0,555$ & $-0,565$ & $-0,578$ & $-0,010$ & $-0,013$ \\
P2 & $-0,526$ & $-0,534$ & $-0,549$ & $-0,008$ & $-0,015$ \\
P3 & $-0,547$ & $-0,562$ & $-0,575$ & $-0,015$ & $-0,013$ \\
P4 & $-0,507$ & $-0,517$ & $-0,530$ & $-0,010$ & $-0,013$ \\
P5 & $-0,644$ & $-0,654$ & $-0,667$ & $-0,010$ & $-0,013$ \\
P6 & $-0,583$ & $-0,593$ & $-0,606$ & $-0,010$ & $-0,013$ \\
\hline \hline
\end{tabular}

Berdasarkan Tabel 5, Perpustakaan mengalami penurunan yang relative sama setiap bulannya. Sisi bangunan yang mengalami penurunan paling besar adalah P2 sebesar $-0,015 \mathrm{~m}$. Letak sisi P5 dapat dilihat melalui Gambar 6 . Sedangkan sisi lainnya mengalami penurunan sebesar $-0,013 \mathrm{~m}$. Berdasarkan Tabel 5 dapat dilihat bahwa bangunan Perpustakaan mengalami penurunan setiap bulannya.

\section{Gedung Rektorat}

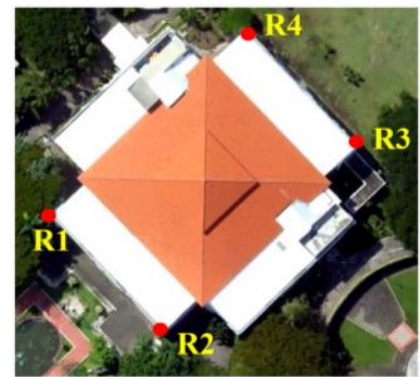

Gambar 2. Gedung Rektorat

Tabel 6. Besar Penurunan Gedung Rektorat

\begin{tabular}{cccccc}
\hline \hline Titik & $\begin{array}{c}\text { Maret } \\
(\mathbf{m})\end{array}$ & $\begin{array}{c}\text { April } \\
(\mathbf{m})\end{array}$ & $\begin{array}{c}\text { Mei } \\
(\mathbf{m})\end{array}$ & $\begin{array}{c}\mathbf{\Delta h}_{1} \\
(\mathbf{m})\end{array}$ & $\begin{array}{c}\boldsymbol{\Delta h}_{\mathbf{2}} \\
(\mathbf{m})\end{array}$ \\
\hline R1 & $-0,664$ & $-0,676$ & $-0,692$ & $-0,012$ & $-0,016$ \\
R2 & $-0,672$ & $-0,679$ & $-0,682$ & $-0,007$ & $-0,003$ \\
R3 & $-0,720$ & $-0,735$ & $-0,742$ & $-0,015$ & $-0,007$ \\
R4 & $-0,720$ & $-0,735$ & $-0,765$ & $-0,015$ & $-0,030$ \\
\hline \hline
\end{tabular}

Tabel 6 menunjukan besar penurunan Gedung Rektorat setiap bulan. Gedung Rektorat mengalami penurunan pada sisi-sisinya setiap bulannya. R4 adalah sisi pada Gedung Rektorat yang mengalami penurunan paling besar dibandingkan sisi lainnya yaitu sebesar 0,030 m. sedangkan R2 adalah sisi yang mengalami penurunan terkecil yaitu sebesar $-0,003 \mathrm{~m}$. Berdasarkan Tabel 6 dapat disimpulkan bahwa Gedung Rektorat mengalami penurunan setiap bulan.

\section{Gedung Lama Teknik Geomatika}

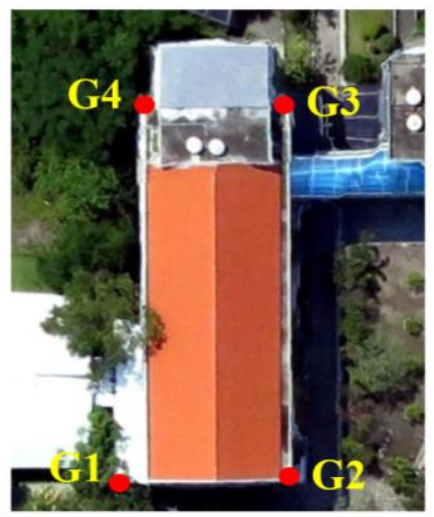

Gambar 3. Gedung Lama Teknik Geomatika

Tabel 7. Besar Penurunan Gedung Lama Teknik Geomatika

\begin{tabular}{cccccc}
\hline \hline Titik & $\begin{array}{c}\text { Maret } \\
(\mathbf{m})\end{array}$ & $\begin{array}{c}\text { April } \\
(\mathbf{m})\end{array}$ & $\begin{array}{c}\text { Mei } \\
(\mathbf{m})\end{array}$ & $\begin{array}{c}\boldsymbol{\Delta h}_{\mathbf{1}} \\
(\mathbf{m})\end{array}$ & $\begin{array}{c}\Delta \mathbf{h}_{\mathbf{2}} \\
(\mathbf{m})\end{array}$ \\
\hline G1 & $-0,406$ & $-0,421$ & $-0,415$ & $-0,015$ & $+0,007$ \\
G2 & $-0,471$ & $-0,488$ & $-0,404$ & $-0,017$ & $+0,084$ \\
G3 & $-0,315$ & $-0,332$ & $-0,240$ & $-0,017$ & $+0,093$ \\
G4 & $-0,343$ & $-0,361$ & $-0,238$ & $-0,018$ & $+0,124$ \\
\hline \hline
\end{tabular}

Tabel 7 menunjukan besar penurunan yang terjadi pada Teknik Geomatika setiap bulan. Apabila dilihat pada tabel, dapat disimpulkan bahwa Teknik Geomatika mengalami penurunan dari pengukuran bulan Maret ke bulan April 2018, Ialu mengalami kenaikan pada pengukuran bulan April menuju Mei 2018. G4 adalah sisi bangunan Teknik Geomatika yang mengalami kenaikan terbesar yaitu sebesar $+0,124 \mathrm{~m}$, sedangkan $\mathrm{G} 1$ adalah sisi yang mengalami kenaikan terkecil yaitu sebesar $+0,007 \mathrm{~m}$. 
Gedung J Teknik Sipil

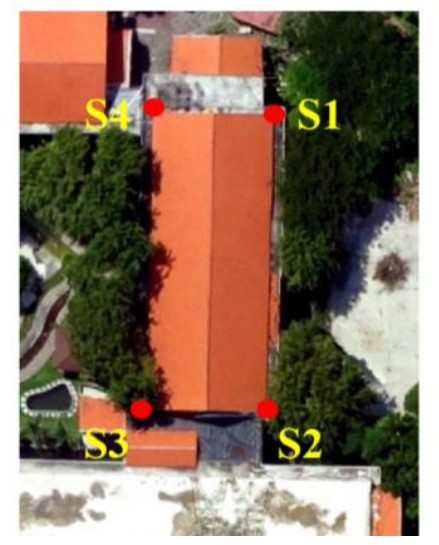

Gambar 4. Gedung J Teknik Sipil

Tabel 8. Besar Penurunan Gedung J Teknik Sipil

\begin{tabular}{cccccc}
\hline Titik & $\begin{array}{c}\text { Maret } \\
(\mathbf{m})\end{array}$ & $\begin{array}{c}\text { April } \\
(\mathbf{m})\end{array}$ & $\begin{array}{c}\text { Mei } \\
(\mathbf{m})\end{array}$ & $\begin{array}{c}\Delta \mathbf{h}_{1} \\
(\mathbf{m})\end{array}$ & $\begin{array}{c}\Delta \mathbf{h}_{\mathbf{2}} \\
(\mathbf{m})\end{array}$ \\
\hline S1 & $-0,325$ & $-0,342$ & $-0,239$ & $-0,017$ & 0,103 \\
S2 & $-0,308$ & $-0,325$ & $-0,244$ & $-0,017$ & 0,081 \\
S3 & $-0,486$ & $-0,501$ & $-0,466$ & $-0,015$ & 0,035 \\
S4 & $-0,230$ & $-0,245$ & $-0,210$ & $-0,015$ & 0,035 \\
\hline \hline
\end{tabular}

Tabel 8 menunjukan besar nilai penurunan yang terjadi pada Teknik Sipil. Apabila diamati, dapat disimpulkan bahwa Teknik Sipil mengalami penurunan pada pengukuran bulan Maret dan April, lalu mengalami kenaikan pada pengukuran bulan April dan Mei 2018. S1 adalah sisi yang mengalami kenaikan terbesar dengan nilai $+0,103 \mathrm{~m}$, sedangkan $\mathrm{S} 3$ dan S4 adalah sisi yang mengalami kenaikan terkecil dengan nilai $+0,035 \mathrm{~m}$.

\section{Gedung Laboratorium Teknik Lingkungan}

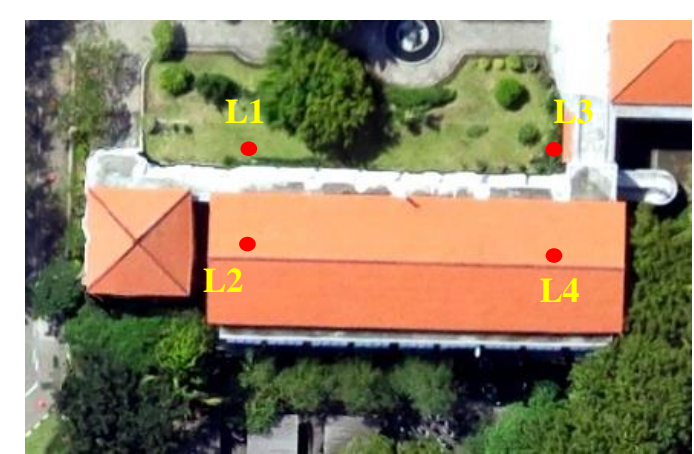

Gambar 5. Gedung Laboratorium Teknik Lingkungan
Tabel 9. Besar Penurunan Gedung Laboratorium Teknik Lingkungan

\begin{tabular}{cccccc}
\hline \hline Titik & $\begin{array}{c}\text { Maret } \\
(\mathbf{m})\end{array}$ & $\begin{array}{c}\text { April } \\
(\mathbf{m})\end{array}$ & $\begin{array}{c}\text { Mei } \\
(\mathbf{m})\end{array}$ & $\begin{array}{c}\Delta \mathbf{h}_{1} \\
(\mathbf{m})\end{array}$ & $\Delta \mathbf{h}_{\mathbf{2}}(\mathbf{m})$ \\
\hline L1 & $+0,021$ & $+0,001$ & $+0,007$ & $-0,020$ & $+0,006$ \\
L2 & $+0,030$ & $+0,010$ & $+0,028$ & $-0,020$ & $+0,018$ \\
L3 & $+0,033$ & $+0,013$ & $+0,020$ & $-0,020$ & $+0,007$ \\
L4 & $+0,049$ & $+0,031$ & $+0,033$ & $-0,018$ & $+0,002$ \\
\hline \hline
\end{tabular}

Tabel 9 menunjukan besar penurunan yang terjadi pada Teknik Lingkungan. Teknik Lingkungan mengalami penurunan pada hasil pengukuran bulan Maret dan April, dan mengalami kenaikan pada pengukuran bulan April menuju Mei 2018. L2 adalah sisi yang mengalami kenaikan terbesar yaitu sebesar +0,018 $\mathrm{m}$, dan L4 adalah sisi yang mengalami kenaikan terkecil sebesar $+0,002 \mathrm{~m}$.

\section{Gedung Biologi}

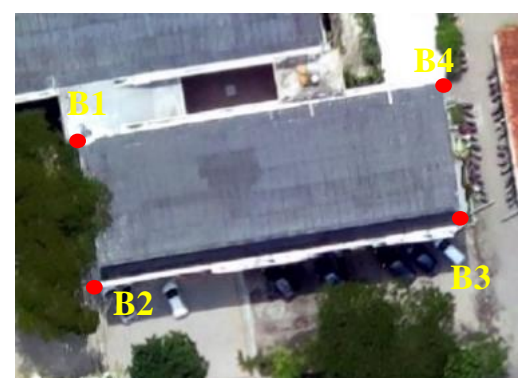

Gambar 6. Gedung Biologi

Tabel 10. Besar Penurunan Gedung Biologi

\begin{tabular}{cccccc}
\hline \hline Titik & $\begin{array}{c}\text { Maret } \\
(\mathbf{m})\end{array}$ & $\begin{array}{c}\text { April } \\
(\mathbf{m})\end{array}$ & $\begin{array}{c}\text { Mei } \\
(\mathbf{m})\end{array}$ & $\begin{array}{c}\boldsymbol{\Delta h}_{\mathbf{1}} \\
(\mathbf{m})\end{array}$ & $\boldsymbol{\Delta h}_{\mathbf{2}}(\mathbf{m})$ \\
\hline B1 & $-0,308$ & $-0,309$ & $-0,322$ & $-0,001$ & $-0,013$ \\
B2 & $-0,523$ & $-0,524$ & $-0,537$ & $-0,001$ & $-0,013$ \\
B3 & $-0,410$ & $-0,410$ & $-0,424$ & 0,000 & $-0,013$ \\
B4 & $-0,534$ & $-0,534$ & $-0,548$ & 0,000 & $-0,013$ \\
\hline \hline
\end{tabular}

Tabel 10 menunjukan besar nilai penurunan pada Departemen Biologi ITS. Pada Biologi, sisi B1 dan B2 mengalami penurunan pada pengukuran bulan Maret menuju bulan April, dan mengalami kenaikan pada bulan April menuju bulan Mei. Sisi B3 dan B4 tidak mengalami penurunan atau kenaikan pada pengukuran bulan Maret menuju bulan April, dan mengalami penurunan pada pengukuran 
bulan April menuju bulan Mei. Setiap sisi bangunan Biologi mengalami penurunan yang relatif sama yaitu sebesar $-0,013 \mathrm{~m}$.

Gedung C Teknik Elektro

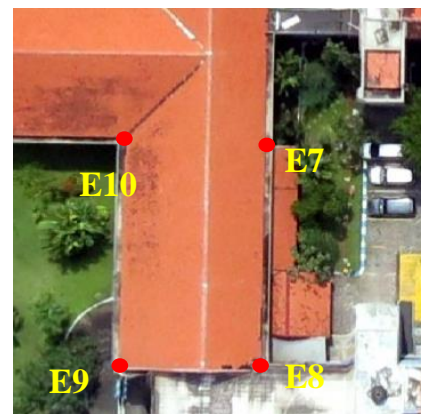

Gambar 7. Gedung C Teknik Elektro

Tabel 11. Besar Penurunan Gedung C Teknik Elektro

\begin{tabular}{cccccc}
\hline \hline Titik & $\begin{array}{c}\text { Maret } \\
(\mathbf{m})\end{array}$ & $\begin{array}{c}\text { April } \\
(\mathbf{m})\end{array}$ & $\begin{array}{c}\text { Mei } \\
(\mathbf{m})\end{array}$ & $\begin{array}{c}\Delta \mathbf{h}_{\mathbf{1}} \\
(\mathbf{m})\end{array}$ & $\begin{array}{c}\Delta \mathbf{h}_{\mathbf{2}} \\
(\mathbf{m})\end{array}$ \\
\hline E9 & $-0,551$ & $-0,563$ & $-0,564$ & $-0,012$ & $-0,001$ \\
E8 & $-0,285$ & $-0,275$ & $-0,219$ & $+0,010$ & $+0,056$ \\
E7 & $-1,138$ & $-1,128$ & $-1,089$ & $+0,010$ & $+0,039$ \\
E10 & $-0,552$ & $-0,563$ & $-0,565$ & $-0,011$ & $-0,002$ \\
\hline \hline
\end{tabular}

Tabel 11 menunjukan besar penurunan yang terjadi pada Teknik Elektro. Sisi E7 dan E8 mengalami kenaikan setiap bulannya. Sedangkan sisi E9 dan E10 mengalami penurunan setiap bulannya. E8 adalah sisi yang mengalami kenaikan terbesar yaitu sebesar $+0,056 \mathrm{~m}$, sedangkan E9 adalah sisi yang mengalami penurunan terkecil yaitu sebesar $-0,001$ $\mathrm{m}$.

Gedung E Teknik Fisika

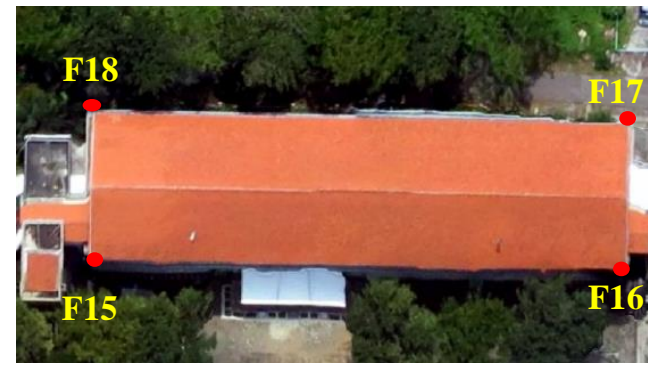

Gambar 8. Gedung E Teknik Fisika

Tabel 12. Besar Penurunan Gedung E Teknik Fisika

\begin{tabular}{cccccc}
\hline \hline Titik & $\begin{array}{c}\text { Maret } \\
(\mathbf{m})\end{array}$ & $\begin{array}{c}\text { April } \\
(\mathbf{m})\end{array}$ & $\begin{array}{c}\text { Mei } \\
(\mathbf{m})\end{array}$ & $\begin{array}{c}\boldsymbol{\Delta h}_{\mathbf{1}} \\
(\mathbf{m})\end{array}$ & $\begin{array}{c}\Delta \mathbf{h}_{\mathbf{2}} \\
(\mathbf{m})\end{array}$ \\
\hline $\mathrm{F} 15$ & $-0,754$ & $-0,792$ & $-0,779$ & $-0,038$ & $+0,013$ \\
\hline \hline
\end{tabular}

\begin{tabular}{llllll}
\hline \hline F16 & $-0,757$ & $-0,795$ & $-0,759$ & $-0,038$ & $+0,036$ \\
F17 & $-0,685$ & $-0,667$ & $-0,697$ & $+0,018$ & $-0,030$ \\
F18 & $-0,614$ & $-0,653$ & $-0,698$ & $-0,039$ & $-0,045$ \\
\hline
\end{tabular}

Tabel 12 menunjukan besar penurunan yang terjadi pada Teknik Fisika. Sisi F15 dan F16 pada Teknik Fisika mengalami penurunan pada pengukuran bulan Maret dengan bulan April, dan mengalami kenaikan pada pengukuran bulan April dengan bulan Mei 2018. F17 mengalami kenaikan setiap bulannya, dan F18 mengalami penurunan setiap bulannya. F16 adalah sisi yang mengalami kenaikan terbesar yaitu sebesar $+0,056 \mathrm{~m}$, dan F17 adalah sisi yang mengalami penurunan terkecil yaitu sebesar $-0,030 \mathrm{~m}$.

Gedung Kimia

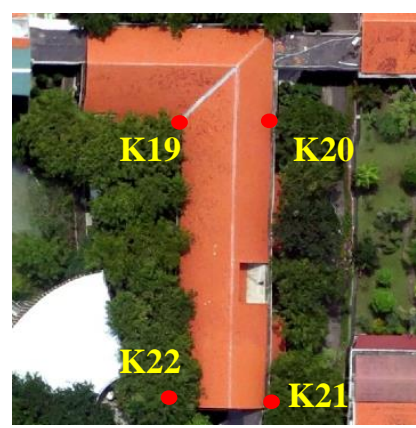

Gambar 9. Kimia

Tabel 13. Besar Penurunan Gedung Kimia

\begin{tabular}{cccccc}
\hline \hline Titik & $\begin{array}{c}\text { Maret } \\
(\mathbf{m})\end{array}$ & $\begin{array}{c}\text { April } \\
(\mathbf{m})\end{array}$ & $\begin{array}{c}\text { Mei } \\
(\mathbf{m})\end{array}$ & $\begin{array}{c}\Delta \mathbf{h}_{1} \\
(\mathbf{m})\end{array}$ & $\begin{array}{c}\Delta \mathbf{h}_{\mathbf{2}} \\
(\mathbf{m})\end{array}$ \\
\hline K19 & $-0,613$ & $-0,652$ & $-0,680$ & $-0,039$ & $-0,028$ \\
K20 & $-0,600$ & $-0,639$ & $-0,667$ & $-0,039$ & $-0,028$ \\
K21 & $-0,461$ & $-0,492$ & $-0,412$ & $-0,031$ & $+0,080$ \\
K22 & $-0,351$ & $-0,388$ & $-0,385$ & $-0,037$ & $+0,003$ \\
\hline
\end{tabular}

Tabel 13 menunjukan besar penurunan yang terjadi pada Departemen Kimia ITS. Mayoritas sisi pada bangunan Kimia mengalami penurunan pada hasil pengukuran bulan Maret menuju April, dan mengalami kenaikan pada pengukuran bulan April dan Mei. K19 dan K20 adalah sisi yang mengalami penurunan terbesar yaitu 0,028 $\mathrm{m}$, dan $\mathrm{K} 21$ adalah sisi yang mengalami kenaikan terbesar yaitu sebesar $+0,080 \mathrm{~m}$. 
Pengukuran beda tinggi menggunakan waterpass untuk mengetahui besar deformasi vertikal yang terjadi pada bangunan bertingkat Kampus ITS Sukolilo menghasilkan beberapa bangunan yang mengalami penurunan. Berdasarkan hasil yang sudah dijelaskan pada sub-bab sebelumnya dapat dilakukan analisa bahwa mayoritas bangunan di Kampus ITS Sukolilo mengalami penurunan setiap bulannya. Besar nilai penurunan yang terjadi relatif sama setiap bulannya. Bangunan yang mengalami penurunan terbesar adalah Teknik Fisika dengan besar nilai $-0,045 \mathrm{~m}$, sedangkan bangunan yang mengalami nilai penurunan terkecil adalah Teknik Elektro dengan nilai 0,002 m. Selain itu, terdapat beberapa bangunan yang juga mengalami kenaikan seperti Teknik Geomatika, Teknik Lingkungan, Teknik Sipil, dan Kimia.

\section{KESIMPULAN}

Berdasarkan pengolahan dan analisis data yang telah dilakukan, berikut adalah kesimpulan yang penulis dapatkan dalam penelitian ini:

1. Salah penutup pengukuran dengan alat Sipat datar untuk menentukan nilai penurunan vertikal Bangunan sebesar $12 \mathrm{~mm}$ untuk Jalur Pengukuran 1 sepanjang $2,5 \mathrm{Km}$ dan $6 \mathrm{~mm}$ untuk Jalur Pengukuran 2 sepanjang 0,5 Km.

2. Nilai deformasi vertikal yang terjadi pada bangunan Kampus ITS Sukolilo dari hasil pengamatan kondisi pada tahun 2018 selama bulan Maret, April, dan Mei adalah Perpustakaan sebesar $-0,013 \mathrm{~m}$, Gedung Rektorat sebesar $-0,016$ m, Teknik Geomatika sebesar +0,007 m, Teknik Fisika sebesar $0,045 \mathrm{~m}$, Biologi sebesar $-0,013 \mathrm{~m}$, Teknik Lingkungan sebesar $+0,018 \mathrm{~m}$, Teknik Elektro sebesar -0,002 m, Teknik Sipil sebesar +0,035 $\mathrm{m}$, dan Kimia sebesar $+0,003 \mathrm{~m}$.

3. Bangunan yang mengalami deformasi vertikal berupa penurunan terbesar adalah Teknik Fisika sebesar $-0,045 \mathrm{~m}$, dan deformasi berupa kenaikan terbesar adalah Teknik Sipil sebesar +0,035 m.

4. Bangunan bertingkat di Kampus ITS Sukolilo mayoritas mengalami penurunan elevasi sejak awal pembangunan. Bangunan yang mengalami penurunan elevasi setiap bulan adalah Perpustakaan, Gedung Rektorat, Teknik Fisika, Biologi, dan Teknik Elektro.
Sedangkan Teknik Geomatika, Teknik Lingkungan, Teknik Sipil, dan Kimia mengalami penurunan dan mengalami kenaikan pada bulan selanjutnya.

\section{UCAPAN TERIMA KASIH}

Penulis R.I.L. mengucapkan terima kasih kepada Direktorat Sarana dan Prasarana Bidang Kearsipan ITS yang telah menyediakan data untuk keperluan penelitian, Bapak Dr. Ir. Muhammad Taufik selaku dosen pembimbing yang telah memberikan dukungan dan bimbingan selama penelitian dilaksanakan.

\section{DAFTAR PUSTAKA}

Das, Braja M. 2002. Principles of Geotechnical Engineering - 5th Edition. Three Lakes: Cole Publishing.

Supriyani, R. O. 2018. Evaluasi Teknis Elevasi Jalan Utama Kampus ITS Sukolilo Surabaya. Surabaya: Teknik Geomatika ITS. 